\title{
IIIISGUCDERGI.ORG
}

"IȘ, GÜç̣" ENDÜSTRi iLIȘKiLERi VE INSAN KAYNAKLARI DERGISi

"IS, GUC" INDUSTRIAL RELATIONS AND HUMAN RESOURCES JOURNAL

\section{Flexicurity And Its Effects On Legal Regulations Throughout Europe}

\author{
S. Alp Limoncuoğlu \\ Asst. Prof. Dr. / Izmir University of Economics \\ alp.limoncuoglu@ieu.edu.tr
}

Ekim/October 2009, Cilt/Vol: 11, Say1/Num: 6, Page: 7-24

ISSN: 1303-2860, DOI: 10.4026/1303-2860.2009.0129.x

Makalenin on-line kopyasına erişmek için:

$\mathrm{http}: / /$ www.isgucdergi.org/?p=makale\&id=402\&cilt=11\&sayi=6\&yil=2009

To reach the on-line copy of article:

http://www.isguc.org/?p=article\&id=402\&vol=11\&num=6\&year=2009

Makale İçin İletişim/Correspondence to:

Yazarların e-posta adresleri verilmiştir. Writers e-mail was given for contact. 
(C) 2000- 2009

"İşGüç̧" Endüstri İlişkileri ve İnsan Kaynakları Dergisi

"İşGüç" Industrial Relations and Human Resources Journal

Ekim/October 2009, Cilt/Vol: 11, Say1/Num: 6

ISSN: 1303-2860, DOI: 10.4026/1303-2860.2009.0129.x

Editör/Editor-in-Chief

Aşkın Keser (Kocaeli University)

Editör Yardımcıları/Co-Editors

K.Ahmet Sevimli (Uludağ University)

Gözde Yilmaz (Kocaeli University)

Uygulama/Design

Yusuf Budak (Kocaeli Universtiy)

\author{
Yayin Kurulu / Publishing Committee \\ Dr.Zerrin Firat (Uludăg University) \\ Doç.Dr.Aşkın Keser (Kocaeli University) \\ Prof.Dr.Ahmet Selamoğlu (Kocaeli University) \\ Yrd.Doç.Dr.Ahmet Sevimli (Uludağ University) \\ Yrd.Doç.Dr.Abdulkadir Şenkal (Kocaeli University) \\ Yrd.Doç.Dr.Gözde Yilmaz (Kocaeli University) \\ Dr.Memet Zencirkıran (Uludağ University)
}

Uluslararası Danışma Kurulu / International Advisory Board

Prof.Dr.Ronald Burke (York University-Kanada)

Assoc.Prof.Dr.Glenn Dawes (James Cook University-Avustralya)

Prof.Dr.Jan Dul (Erasmus University-Hollanda)

Prof.Dr.Alev Efendioğlu (University of San Francisco-ABD)

Prof.Dr.Adrian Furnham (University College London-İngiltere)

Prof.Dr.Alan Geare (University of Otago- Yeni Zellanda)

Prof.Dr. Ricky Griffin (TAMU-Texas AEM University-ABD)

Assoc. Prof. Dr. Diana Lipinskiene (Kaunos University-Litvanya)

Prof.Dr.George Manning (Northern Kentucky University-ABD)

Prof. Dr. William (L.) Murray (University of San Francisco-ABD)

Prof.Dr.Mustafa Özbilgin (University of East Anglia-UK)

Assoc. Prof. Owen Stanley (James Cook University-Avustralya)

Prof.Dr.Işık Urla Zeytinoğlu (McMaster University-Kanada)

Danışma Kurulu / National Advisory Board

Prof.Dr.Yusuf Alper (Uludağ University)

Prof.Dr.Veysel Bozkurt (Uludağ University)

Prof.Dr.Toker Dereli (Işık University)

Prof.Dr.Nihat Erdoğmuş (Kocaeli University)

Prof.Dr.Ahmet Makal (Ankara University)

Prof.Dr.Ahmet Selamoğlu (Kocaeli University)

Prof.Dr.Nadir Suğur (Anadolu University)

Prof.Dr.Nursel Telman (Maltepe University)

Prof.Dr.Cavide Uyargil (İstanbul University)

Prof.Dr.Engin Yildırım (Sakarya University)

Doç.Dr.Arzu Wasti (Sabancı University)

Dergide yayınlanan yazılardaki görüşler ve bu konudaki sorumluluk yazarlarma aittir.

Yayınlanan eserlerde yer alan tüm içerik kaynak gösterilmeden kullanılamaz.

All the opinions written in articles are under responsibilities of the outhors.

None of the contents published can't be used without being cited. 


\title{
Flexicurity And Its Effects On Legal Regulations Throughout Europe
}

\author{
S. Alp Limoncuoğlu \\ Asst. Prof. Dr. / Izmir University of Economics
}

\begin{abstract}
:
Globalization, the acceleration of economic integration, technological advancement which enables the SMEs to compete with big companies, ageing population, the low rate of birth and the segmentation of labour force during 1980 's and 1990's are the foundation of European Employment Strategy which was created in 1997. The strategy is followed by the most important objective put forward in Lisbon Strategy of 2000 that shaped Europe's first decade of 21st century: making the EU "the most competitive and dynamic knowledge-based economy in the world, capable of sustainable economic growth with more and better jobs and greater social cohesion". The Lisbon Strategy constitutes a dilemma, however, for European companies, institutions, governments, labour force and the EU itself. The companies need to work in a flexible labour markets, flexible work organizations and flexible employment conditions to compete and survive in a global economy. The labour force, on the other hand, needs strengthened social security, especially increased social programs for vulnerable groups alongside the flexibility options for increased quality of life. The remedy of this dilemma is one of the most important current socio-political subjects of Europe : Flexicurity.
\end{abstract}

This article investigates the born and the meaning of the term flexicurity, its principles and elements and its effects on the labour regulations throughout Europe. The legal changes in different countries from different social model within Europe are presented. The flexicurity programs in Turkish labour legislation are also taken into account to make a comparison as the country wants to join EU in near future.

Keywords:Flexicurity, Labour Law, Economic integration, Globalization 


\section{Flexicurity}

The definition of flexicurity in academic literature is numerous. In its shortest form, flexicurity is defined as social security for flexible workforce (Keller and Seifert 2004; Klammer and Tillman 2001; Ferrera et al 2001). In a new work, the flexicurity is defined as increasing labour market mobility with opportunities to get a new job and not to lose out substantially in terms of income level (Eamets and Paas 2007). But the most commonly referred definition is belong to Wilthagen: "A policy strategy that attempts, synchronically and in a deliberate way, to enhance the flexibility of labour markets, work organisation and labour relations on the one hand, and to enhance security-employment security and social security-notably for weaker groups in and outside the labour market, on the other hand" Wilthagen 1998; Wilthagen and Rogowski 2002; Wilthagen and Tros 2004). Wilthagen and Tros (2004) pointing out the difficulty of defining flexicurity in terms of political strategy, made another definition by stating that "flexicurity is (1) a degree of job, employment, income and 'combination' security that facilitates the labour market careers and biographies of workers with a relatively weak position and allows for enduring and high quality labour market participation and social inclusion, while at the same time providing (2) a degree of numerical (both external and internal), functional and wage flexibility that allows for labour markets' (and individual companies') timely and adequate adjustment to changing conditions in order to maintain and enhance competitiveness and productivity". These definitions, however, is criticised of not being and supported by numerical outputs. Tangian, as one of these critics, implies the term as the social security and employability of workers by atypical contracts (Tangian 2005).

One may think that the term flexibility and security are contradictory but this is mistaking. European Expert Group on Flexicurity (2007) states than the two terms are mutu- ally. Madsen (2006) argues that if both term can be used mutually supportive, a win-win scenario can be created.

It should be noted here that up until now, the best analytical framework for flexicurity is known as Wilthagen Matrix (Wilthagen et al 2003). This matrix has two axis called flexibility and security, each one of them is categorized under 4 sub-headings. The categorization of flexibility is made according to Atkinson's well known flexible firm (Atkinson 1985) as external numerical flexibility, internal numerical flexibility, functional flexibility and wage flexibility. The categorization of security on the other hand, is made by Wilthagen and his co-workers as job security, employment security, wage security and combination security. The original matrix was created to show the sacrifices it should be made to balance both term (Wilthagen and Tros 2004).

As the term flexicurity gained importance and became one of the main subject European policy makers work on the contribution of the social parties are needed. In 2006, European Commission organized Tri-partite Social Summit with the attendance of employers' and employees' organizations (European Foundation for the Improvement of Living and Working Condition 2006). At the end of the summit, the parties agreed that some common components are necessary in order the national flexicurity programs succeed. These components are states as: (i) Flexible and reliable contractual arrangements; (ii) Comprehensive lifelong learning; (iii) Effective active labour market policies; and (iv) Modern social security systems.

Bekker and Wilthagen (2008) add the development of a supportive and productive social dialogue as the fifth component. European Social Partners (2007) also accepts this opinion. With these developments, flexicurity sits now in the centre of European Employment Strategy for 2008-2010. It should also be mentioned that as every European country has a different employment model and policy, one prescription is im- 
possible to describe in order to establish a perfect flexicure policy. Therefore the common principles were developed in order to facilitate national debates within the common objectives drawn by EU (European Commission 2007). The details of these principles can be obtained from the work of the union.

The work is about the effects of flexicurity on legal regulations throughout Europe. Flexicurity implementations in Denmark and Netherlands are researched because those countries are the first ones that experienced flexicurity policies and realized success. Austria is also chosen as the country's severance pay reform is shown example of best practice around Europe. As the social state models of three countries are similar, the fourth country is chosen from liberal social state model: U.K.

\section{The Application of Flexicurity in Danish Law}

As it is stated above, the first country the flexicurity has been implemented is Denmark. Denmark, however, has a quite important specialty in this manner. The researchers has pointed out that Danish labour legislation and industrial relations system has been historically carrying the characteristics of flexicurity, since long before the term is started to be used. The other countries, on the other hand, have started to coordinate their legislation according to flexicurity principles after the success of the system in Denmark and Netherlands.

Danish labour market model is called "golden triangle" in the academic literature (Madsen 1999, 2002, 2003, 2006; Bredgaard et al 2005, 2006). The model, as Madsen points out, characterized by the combination of "a flexible labour market with grants high levels of worker flows in and out of employment and unemployment, a generous system of economic support for the unemployed and active labour market policies". High level of worker flows is described by the term job mobility in the European litera- ture. For the job mobility to be high, the job security arrangements within a country should be limited. Strict rules of job security do not only limit the possibility for employers to end the employment contract by their own initiatives but they also affect their hiring decisions negatively. Therefore, job security and job mobility is reciprocal. Danish labour law, according to this principle, obtained its job mobility characteristics via the low level of job security arrangement deriving from its historical background (Bredgaard and Larsen 2007). Since the 1899 September Compromises between the the Danish Confederation of Trade Unions (LO - Landsorganisationen) and the Confederation of Danish Employers (DA - Dansk Arbejdsgiverforening), the employers in Denmark carry broad freedom in their hiring and firing decisions. These compromises are also important in labour law history as being one of the first examples of legislation made by the agreement of social partners (Larsen and Jørgensen 2002). We should refer here to World Bank's report of "Doing Business in 2004 - Understanding Regulations" while researching the flexibility of labour legislation. This report takes account three criteria to describe the flexibility. Those are the flexibility of hiring, the flexibility of firing and employment conditions. According to the report, Denmark has the second flexible labour market in terms of hiring, third flexible labour market in terms of firing and the most flexible labour market in terms of employment condition. Altogether, it is called as the country that has the most flexible labour law within Europe. A similar work, made by OECD, analyses the rigidity of employment protection legislation of $\mathrm{Co}-$ untries (OECD 2004). This work also deals with three criteria. The first one is the difficulty of dismissal. It is involved with the scope of "justified" or "fair" reasons in each country. The second one is the procedural inconveniences that the employer may face when starting the dismissal process. The third and the last criterion is notice and severance pay provisions. According to the 
first one Denmark is considered the second most flexible country among its European peers. It is the most flexible country according to the second criterion. The country is on the middle of the table only for the third one.

The notice and severance pay in Denmark are mostly regulated by collective agreements. Beside there exist White Collar Workers Act. The act include some how a rigid notice obligation for the employers. The regulation about severance payment is limited though. The employers do not have any notice obligation for the contracts of less than 6 months. For longer contracts, the employers' obligations of notice increase gradually. For a 12-years long worker, the notice period reaches to a maximum of 120 days. The employees, on the other hand, need to work at least 20 years to be entitled to severance pay. But as the job mobility rate is quite high, it can be considered to be hard to find someone with such an experience with the same employer.

The root of the unemployment insurance application in Denmark can be found in Ghent system. The system which was accepted in 1907 was reshaped in 1969. The main principles of the system are its being generous both in term of scope and contribution and its financial structure which is mostly governmental (Bredgaard and Larsen, 2007). The system is optional but according to OECD it covers $90 \%$ of the labour force. The employees who pays unemployment insurance premium at least for one year and who have worked at least 52 weeks in the last 3 years are allowed to benefit from the system when they get unemployed. Opposite to most countries, the reason of unemployment does not matter in Denmark to get entitled for such a benefit. Unemployment insurance pay has been set to $90 \%$ of the workers' previous wage and it is been paid for a maximum of 4 years. This is a quite long time in comparative application.

Active labour market policies are quite new subjects compared to labour market flexibility. Labour market policies in Denmark have been developed in 1950's (Madsen 2006). The reform on policies was made in 1993 and 1994. Danish industrial relations have experienced a shift from job security to employment security with these reforms. The vocational education policies that have been enacted in 1960's are administered by social parties for the last 10 years. The financial support however comes from the government. Therefore, educational activities are considered not on company but on general basis. While unemployed people and those who stay out of labour market were on the centre of policies before, new reforms are mostly focussed on the employability and abilities of the current workers. Job rotation is an important instrument (Wilthagen et al 2003). Workers who attend to job rotation programs gain experiences while working on their new assignments, while unemployed people are placed to their works instead. Beside, a similar program for unemployed people is developed for the workers who use their paid leave rights. According to Schmid and Schömann's (1999) calculation one third of such people were employed by the employer even after the main employee returned to his/her job.

The workers' leaves in Denmark, other then annual paid leave, are pregnancy leave, parental leave and paternity leave. Sabbatical leave and educational leave are no longer in use. Opposite to other countries' implementation no leave right is granted due to children' health reason. But these kind of leaves are broadly regulated and used in collective agreements (Pylkkanen and Smith 2004). A pregnant woman who has worked at least 13 weeks has the right to use a pregnancy leave of 18 weeks starting 4 weeks before the delivery. The laws state that a minimum of $90 \%$ of previous wage is obligatory for anyone who has not been awarded a payment option by the employer. For the public sector workers, on the other hand, this amount is $100 \%$. Fathers have also a two-week paid (90 $\%)$ paternity leave right. Parents have an additional 32 weeks parental leave right in Denmark. This leave can be used starting from 14th week after the birth or after mot- 
her has used her maternity leave right. This right may also be used partially or working pat-time in accordance with the internal numerical flexibility policies. It should be noted that part-time working pulls a lot of attention lately. A Law which regulates part-time working is enacted in 2002, but the implementation of such a employment style have been in use since long time. The law on the other hand grants job security for workers who ask reduction of their working hours.

Another point which should be mentioned about effective active labour market policies is the reform made in 2006 and 2007 which lowered the labour market organization from 14 different regions to 5 and limited their responsibilities. The aim was to enable local governments to play more effective role. This is a decentralization policy.

Below is the Danish "golden triangle" model shown in a scheme. rity system which is called generous welfare system in the scheme. As the limitation to hiring and firing is quite low, it has been determined that a lot of people move in and out of the employment system (Ministry of Employment, 2005). A part of the unemployed people finds a new job and move in to the employment market, while the other part reaches the same spot by the help of active labour market policy. Two important effects of active labour market policy are also highlighted in the scheme. The first one is the qualification effect which is mostly the result of education and systems like job rotation mentioned above. The unemployed people who gained new abilities are suited to more jobs than before. The second effect is motivational. An unemployed person who normally shall not return to labour market starts to look for new job by the help of new policies.
Figure 1

Danish flexicurity model : Golden Triangle

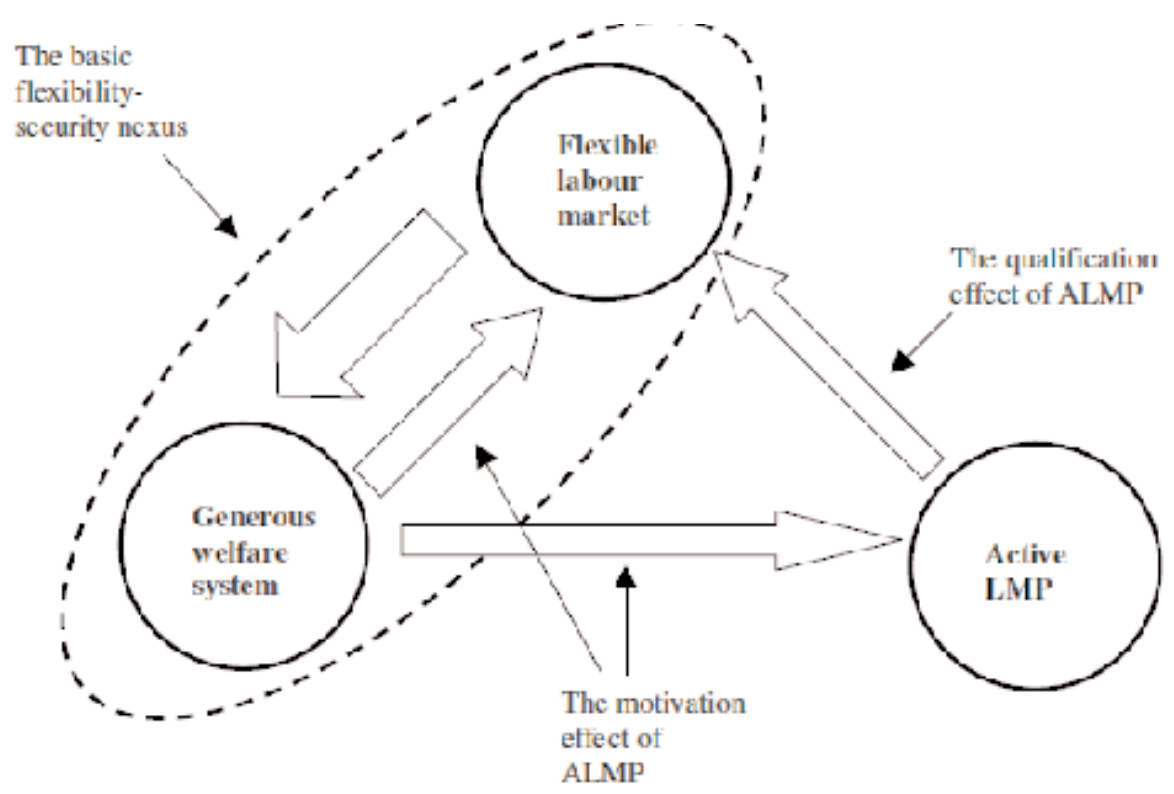

Source : Madsen (2006)

\section{The Application of Flexicurity in Dutch Law}

Netherlands is the first country where the term flexicurity is used. The flexibility and security discussions are the popular subject of 1990 's in the country. Historically job security understanding and regulations became very strict and as in all around Europe, Dutch companies were insisting on having flexible employment relations in order to stay alive in global economy. Dutch employers were unable to fire The arrows in the scheme show workers / people flow. There is a continuous flow between flexible labour market and social secu- employees on their own initiative. They either have to take the approval of regional public employment service (CWI - Centrum 
voor Werk en Inkomen) or have to apply to court to annul the contract due to "serious causes". The program declared by Ad Melkert, the Minister of Social Relations and Employment, in 1995 was about the flexibility of these conditions and to loosen the approval instrument (Wilthagen and Tros 2004). However, the elimination of the approval procedure was only suggested for temporary work relations. The program was promoting atypical employment models. Temporary workers agencies were favoured (Bekker and Wilthagen 2008).

In 1996, another legal regulation that favoured atypical employment model was enacted by Prohibition of Discrimination by Working Hours Act (Wet Verbod onderscheid arbeidsduur). The employers are forbidden to treat differently to part-time or temporary workers then permanent workers. The articles of employment contract which are against these rules were accepted non existent. Another main purpose of the Act was to balance workers work - life balance. Therefore the Act regulates the employers and employees power to determine their work hours. Adjustment of Working Hours Act which was enacted in 2000 provides an individual right of employees to increase or decrease their working hours. The employers' objection right were limited. The decisional power however is on the hand of the employers and the employees who are not satisfied with the decision have the right to go to the court. The regulation is effective for companies with more than 10 employees. If we look into the courts decisions on the subject up to not, we can point out that the decisions are mostly in favour of employees and the Courts usually give the employers the power to determine how the employees will recover their missing working hours.

The effects of these two Act is very important in the Netherland. $46 \%$ of the work force is working with part-time and this rate is more than $60 \%$ among women (Limoncuoğlu 2008). Most of the employee declares that the choice of working part-time was their decision. (Bakker and Wilthagen 2008).
Another important legal regulation on the subject is the Flexibility and Security Act (Wet Flexibiliteit en Zekerheid) of 1999. The Act is the result of the agreement of social parties called Labour Foundation (Stichting van de Arbeid). The purpose of the Act is to make traditional employment relations more flexible and to increase the security of flexible workers. The changes made by the Act are summarized as:

- companies can use temporary employment contracts more than they could in the past;

- a series of consecutive temporary employment contracts will, under certain conditions, lead to a permanent employment contract;

- agreements between employees and temporary employment agencies will now be considered as employment contracts;

- notice periods are shortened and simplified;

- procedures for dismissal on economic, technical and organisational grounds are shortened; and

- unemployment benefits are reduced if the employer awards severance pay.

In 2006, the obligations of the employers arising from the regulation on health and safety on work were reduced. Another change was made on the shop's working hours and the shop owners were granted to work longer hours and on weekends.

With all these changes, it should be noted here that Netherlands is shown as a model country with its temporary employment relations models. Part-time work is one type of these temporary employment models and the regulation which enabled the rise of this model in Netherlands is Wassenaar Agreement of 1992 also known as Central Recommendations Regarding Aspects of an Employment Policy. The focuses of these recommendations are wages, working hours and job sharing. While the unemployment level was above the $10 \%$ threshold in that 
time, the unions agreed not to ask any rise on employees' wages, the employers, on the other hand, accepted the decrease on working time and instruments like job sharing. The agreement was aiming at reducing the unemployment level by early retirement policies and part-time work opportunities. Up until this agreement, the workers' wages was increasing automatically according to wage index (Watson et. al. 1999). Therefore, Wassenaar Agreement is accepted as a cornerstone of Dutch labour market history. (Schippers et al 2006). unemployed people to look for and accept the jobs. Another limitation was enacted at Work and Income according to Labour Capacity Act (Wet werk en inkomen naar arbeidsvermogen). However, I believe that this limitation contradicts with Wilthagen's first flexicurity definition of "...to enhance security - employment security and social security - notably for weaker groups in and outside the labour market, ...". The "last in first out" principle in labour law was also eliminated.
Figure 2

Dutch flexicurity model : (Silver) Square of Turst

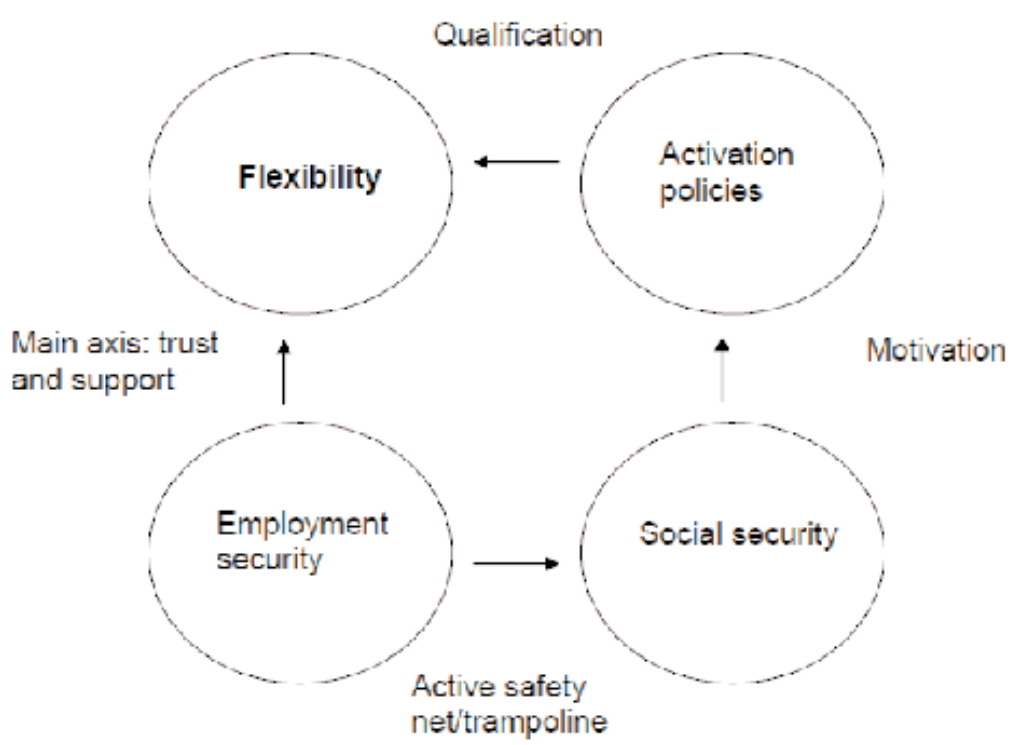

As the Danish flexicurity model is called "golden triangle", a similar qualification is made for Dutch system. It is called "silver square" or "square of trust" (Schippers et al 2006). The scheme designed by Wilthagen is shown above. The four corners of this square are flexibility, employment security, activating policies and social security. The arrows show the flow of people here too. People move in and out of employment due to flexible hiring and firing regulations. When they become unemployed, it is relatively easy for them to find new jobs by the help of employment security policies. It is not possible however to form a labour market which has employment security and flexible. Serious legal regulations and trust between employers and employees are needed. Therefore, trust and support are accepted as main axis of the scheme. Employment security is insufficient though. Unemployed people are in need of wage and other social securities. This can be ensured by country's social security system. All people in labour market system should be covered by an active safety net. The efpurpose of such limitation is to motivate the 
fective social security for unemployed people is good but it should be missing if the system does not help the unemployed people to return to employment. People should be motivated by the help of activation policies. Two important notions here are employability and education.

\section{The Application of Flexicurity in Aus- trian Law}

The reason Austrian labour law forms an example of flexicurity practices around Europe is its reform on severance pay. But before going through it, the general flexicrutiy framework in Austria should be mentioned.

One can say that there exist a serious external numerical flexibility in Austrian labour law. There is no limitation in hiring and the biggest problem in firing for employers is notice period. Employers are free to terminate the employment contract if there is a just cause committed by or arise from the employee. In other conditions, a notice should be given prior to termination. This period is different for blue and white collar workers. For blue collar workers, there exist a general 14 days notice period regulated by Commercial Bylaw. This period does not increase or decrease according to working length. The regulation on the other hand gives the collective agreements a priority. White Collar Workers Act set a minimum of 6 weeks notice period for workers and this period increases according to workers' employment length reaching to a maximum of 5 months after 25 years. We should mention however that labour force mobility in the country is quite high so only limited proportion of the labour force is entitled to maximum notice period. It is noted by Lehner and Timar (2006) that the employment contracts of one third of the labour force end each year.

The employers have the authority to arrange the working time of the employees within the maximum limit regulated by law. Wages are also considered flexible as no strict limitation exists about the decrease in the wages. Any such decrease however should be made with the employee's and the trade union's approval.

The job security regulations are not strict either. This facilitates the authorities' performance to implement flexicurity regulations as they don't have to deal with job security issues much. The approval procedure before the end of the contract is also accepted in Austrian labour law but only for selected workers such as the members of works councils, those who are on pregnancy or parental leave, who perform their military duty, etc. Though job security regulations are not strict, it is also hard to say that Austria has already a successful employment security system. Only one third of the workers who lose their job in a year are able to find a new one (Lehner and Timar 2006).

We cannot praise the wage security system either. The scope of the unemployment security system is narrow and the benefits are low. It is an obligatory system. In general, only those who worked at least 52 weeks during last 24 months are able to be entitled for such benefit, but this rule only applies to unemployed people who are above 25 years old and previously not entitled for such a benefit. The ones that have benefitted from unemployment insurance and those who are below 25 years old have easier condition to be re-entitled. The reason of annulment of the contract does not affect the entitlement, it does just delay it. The benefit is usually $55 \%$ of the worker's previous wage and the minimum benefit duration is 20 weeks while the maximum is 52 (Public Employment Service Austria).

Combination security is a popular subject. Maternity Protection Act of 1979 was updated twice in the last 10 years. The first update was about childcare benefit and the second one was about part-time working right (Drew 2005). The pregnancy leave is in comfort with EU's Regulation 92/85. The parental leave is regulated by Parental Leave Benefit Act (Karenzgeldgesetz) in 1997 which also changed some provisions of Unemployment Insurance Act (Arbeitslosenversicherungsgesetz) of 1977. Sabbatical 
leave is also possible. Part-time work is encouraged by law. In 2002 a new regulation made possible for workers to use family care leave.

The education is seen as an important tool in the implementation process of active labour market policies. Those who have at least three years working experience have the right to take at least 3 and utmost 1 year educational leave. They have wage security during this leave. In 2004 a new educational career program is accepted about those who are above 40 years old. In 2005, more than 60.000 people are covered by a new employment program with Employment Promotion Act

But apart from those programs, severance pay reform is the most important flexicurity implementation in Austria. The foundation of Austrian severance pay system lies on Salaried Employees Act (Angestelltengesetz) of 1921 and Wage Earners' Severance Pay Act (Arbeiterabfertigungsgesetz) of 1979. Accordingly, an employer did not have to show any reason while ending the employment contract of a worker. It did however have to make a severance payment. The worker was in need to work at least 3 years with the same employer to earn such a pay. The pay was increasing with the length of the work experience. The financial burden was on the shoulders of the employers. The employees who end the contract themselves were not entitled for such a pay.

This system was criticised for a few serious reasons: (i) The scope of the system is narrow; (ii) The employees were unable to receive their payment once the employer faced financial problems; and (iii) The system works against the job mobility. These criticisms lead the creation of a new severance pay act (Betriebliches Mitarbeitervorsorgegesetz) in 2002. The most important characteristic of the system was its financial structure. The employers, in the new system, are only the debtors of severance pay contributions to a new Fund as they do in social security contributions. Once the employment contract ends, the employees shall re- ceive their severance pay from the Fund. The employees shall not lose their severance pay right once they end the employment contract under the new system. They will not get paid under this condition but their money in the Fund will keep earning interest. The conditions to be entitled to a severance pay did not change for this reason. Employees will receive their severance pay once the relationship ends the way the Act describes. They have the option not to take the money from the Fund and let it gain more interest for the future. The retirement is accepted, however, as a reason to be entitled for such a payment. The employee shall also be entitled to his money in the Fund if he/she leaves the labour market for 5 years (Klec 2007).

I have to mention one more time that the reform is shown as an example in European Commission works due to its ability to remove one of the most important limitations on external numerical flexibility (job mobility) (European Commission 2007). The system also turns to a second level retirement program for those who do not want to collect their money from the system. Accordingly it is also an example of wage security program.

\section{The Application of Flexicurity in British Law}

As a result of being a representative of liberal social state understanding, flexicurity implementations in U.K. mostly favours flexibility. Wage security is very low to promote people towards employment and the state intervention to labour market was limited. According to OECD 2004 Economic Outlook, U.K. is one of two countries that have the most flexible employment system. The developments and debates in Europe however has also started to show its effect in U.K. in the new millennium. While the new legislation effort takes employers' flexibility requests into account, it also focuses to security issues. Life long learning programs and active labour market policies have also seen a lot of changes since then.

As we are well aware now, one of four com- 
ponents of flexicurity is flexible and reliable contractual agreements. Legal foundation should be proper for this. One of the most important development within this era is the new Employment Rights Act of 1996. The Act is very broad in the scope and redesigned most of the employment relationship. When we look into the Act, we may see that the regulations are about protection of wages, guarantee payments, Sunday working for shops, protection from suffering detriment in employment, leave provisions, suspension from work, termination of employment, unfair dismissal and its remedies, etc.

The notice period and severance pay exist in U.K. but it is hard to say they constitute a limitation in front of employment flexibility, job mobility. The minimum notice period for employers is set to one week for the workers who worked less then two years. The amount is increased one week for each year of severance. The notice period for employees on the other hand is one week flat. Severance pay differs according to employee's age. For the ones who are over 41 , the severance pay is equal to one and half weekly wages for each years of severance, while it is one weekly wage for the ones who are between the ages of 22 to 41 . For all others, it is half weekly wages. A research made by Mercer Human Resources Consultancy Group shows that severance pay in U.K. is the third lowest in Europe behind Netherlands and France.

There exists some wage security regulations in the Act. The articles of 13 to 27 are about the protection of wages. It is forbidden by law to decrease the wages. Beside these regulations, the employees are also protected against the risk of not getting any job from the employer (articles 28-35). While the regulations about Sunday and late time working of shops is about functional flexibility (articles 36-43), leave provisions are about combination security (article 50-63), the provisions about pregnancy and maternity leave are about combination and wage security (articles 71-85).
Job security in U.K. is quite similar to its other European counterparts. It is forbidden by law for employers to end the employment contract without fair reasons. These reasons can be the result of employee's abilities, qualities and/or conducts. The party who claim that the dismissal was unfair should take the case to the court. The remedies against unfair dismissal are also stated in the Act.

Employment Rights Act is not the only one that regulates flexicurity in U.K.. Employment Relations Act of 1999 and Employment Act of 2002 are the other ones. In 2006 Work and Family Act has been enacted. The last two acts mentioned here are mostly about the work-life balance principle and related to combination security and internal numerical flexibility.

The length of the maternity leave is set to 52 weeks with the legal change made in 2007. In 2002 an obligatory paternity leave and pay instruments are created. The parental leave right is regulated in 1999. Apart from the general regulations on part-time employment, the laws updated in 2002 and 2006 enforce the employers to seriously consider any employees' requests to work parttime.

These legal regulations mentioned above are not only about work-life balance issue. It also includes some new forms of flexible employment models. For example, there are anti-discrimination regulations in the Employment Relations Act of 1999 toward parttime workers. A similar principle is accepted for fixed-term contracts in 2002. Temporary agency workers on the other hand are stil without such protection. Bren (2006) state that discrimination provisions are enlarged to cover workers of all age in 2006.

As can be seen, U.K. is experiencing a lot of new legal regulative action for the last 10 years. But these regulations are not only on the employer-employee axis. A new program about active labour market policies was accepted in 1998. The name of the program is New Deal and its purpose is to increase 
employment. Disadvantaged groups are favoured. The segmentation in U.K. labour market is one of the main reasons for such program. A mentor is assigned for every person that attends to the program and this mentor helps to person in finding new jobs, developing his/her abilities and increasing his/her experiences. New Deal program has 7 sub section and is very broad in scope.

It is better at this moment to look into British unemployment insurance system. The roots of the system lie in the beginning of 20th century. Not surprisingly, the reform on the system was made in 1995. According to the name of the Act, the name of the unemployment benefit has also changed to Jobseeker's Allowance. This allowance can also be divided to two as "Contribution-based Jobseeker's Allowance" and "Income-based Jobseeker's Allowance". Those who earn more than weekly threshold are subjects to the first one and vice versa. Contribution based allowance lasts up to 6 months while there is no time limitation for the other one.

The last development about active labour market policies in England is the program which tries to increase the employability of those under the incapacity benefits and lone parents. The incapacity benefits is a social security program that makes wage payments to people who can not work due to his/her sickness or disability. In 2008, this benefits replaced by Employment Support Allowance. The governments aim is to increase the employment level of lone parent to $70 \%$ (Bren 2006).

One last point will be about life long learning program in the country. U.K. has increased its related budget during the last 10 years. While the money hold for this reason was about 4,5\% of GDP in 1997, it increased to $5,5 \%$.

\section{Conclusion and Comparison with Turkish Labour Law System}

It is surprising to see that while Europe is dealing with flexicurity regulations and the shift in the policies is from job security towards employment security, Turkish po- licymakers try to increase job security of the employees. Job Security Act no. 4773 is enacted in 2003. Even before this regulation, Turkish employment system is seen inflexible because the strictness of its notice and severance pay provisions. The highness of firing cost was always seen as the major limit in front of external numerical flexibility. It was also hard to talk about wage flexibility and combination security in Turkey as it was and still is forbidden to decrease the workers wages and there is nearly no discussion of work-life balance.

The new Labour Act no. 4857, which was accepted in 2003, contains some flexible types of employment however. Part-time work; work on call and temporary agency work are regulated according to European regulations. As these types of employment models have no place in previous Labour Act, it is possible to say that flexibility is on the agenda of the Labour and Social Security Ministry. While job security provisions affected the numerical flexibility negatively, the introduction of new atypical employment models has shown positive effects. The new Labour Act also includes flexible provisions about working time but mostly at the initiative of employer. Short time work and temporary work can also be shown as examples of the flexible characteristic of the new code.

Maternity rights are in accordance with EU Directives but Turkey is still one of the few countries within Europe that does not grant paternity leave or parental leave to husbands. Educational leave and sabbatical leave do not exist. Childcare provisions and benefits are really limited in comparative law.

In comparative researches, Turkey fall way behind of its European counterparts in employment security level. This is mostly due to the strictness of job security provisions mentioned above. Unemployment Insurance Act no 4447 and the regulations about short time work are good examples of wage security policies, though the scope of these new instruments stayed very limited. There exist also strong arguments about new Social In- 
surance and Universal Health Insurance Law no. 5510, complaining that the Law limits the benefit system. The social security system is modernising but the coverage is still poor. Labour market policies on the other hand are developing but the budget separated for this is quite low.

As a result, it should be said that the flexicurity is not on the agenda of Turkish policy makers. The term is even new among academicians. Policy makers should be aware that any regulations about labour market have the potential to damage the balance between flexibility and security further and this may delay Turkey's journey into to the EU. As the term was born in an attempt to make European economy more competitive and ready for global changes, to make the economic growth sustainable, Turkish policy makers should also realize the importance of the flexicurity independent from political debate between employers and employees organizations.

\section{REFERENCES}

Andersen, S.K. ve Mailand, M. (2005), "The Danish Flexicurity Model - The Role of the Collective Bargaining System", Compiled for the Danish Ministry of Employment, Employment Relations Research Center, Department of Sociology, University of Copenhagen

Atkinson, J. (1985), "Flexibility, Uncertainty and Manpower Management", IMS Report No.89, Institute of Manpower Studies, Brighton.

Bekker, S. ve Wilthagen, T. (2008), "Flexicurity - a European Approach to Labour Market Policy“" Intereconomics Review of European Economic Policy, 43 (2), 68 -73 .

Bonoli, G. (1997), “Classifying welfare states: a two-dimension approach", Journal of Social Policy, 26 (3), 351-72.

Bredgaard, T. ve Larsen F. (2007), "Comparing Flexicurity in Denmark and Japan", JILPT Research Report, Tokyo: Japan Institute for Labour Policy and Training (JILPT), Tokyo.

Breen, E. (2006), Contribution to the EEO Autumn Review 2006 "Flexicurity" UK, European Employment Observatory.http:/ / www.eu-employmentobservatory.net / resources / reports/UK-FlexicurityAR06.pdf

Brunning, G. ve Plantenga, J. (1999), “Parental leave and equal opportunities: experiences in eight European countries", Journal of European Social Policy; 9 (3), 195-209.

Castles, F. G. ve Mitchell, D. (1993), “Worlds of Welfare and Families of Nations", Families of Nations: Patterns of Public Policy in Western Democracies, der. F. G. Castles, Aldershot, Dartmouth. 
Council of the European Union (2007), Towards Common Principles of Flexicurity - Council Conclusion (06 December 2007), Council of Employment, Social Policy, Health and Concumer Affairs, 16201/07, Brussels.

Drew, E. (2005), "Parental Leave in Council of Europe Member States", Council of Europe, Directorate General of Human Rights, Strasbourg.

Eamets, R. ve Paas, T. (2007), “Labour market flexibility and flexicurity", Labour market flexibility, flexicurity and employment: Lessons of the Baltic states, der. Paas, T. and Eamets, R., New York, Nova Science.

Esping-Anderson, G. (1990), The Three Worlds of Welfare Capitalism, New Jersey, Princeton University Press.

European Commission (2004), "Employment in Europe 2004", Directorate-General for Employment and Social Affairs, Brussels. http://ec.europa.eu /employment_social/employment_ana lysis/employ_2004_en.htm

European Commission (2007), "Towards Common Principles of Flexicurity: More and Beter Jobs Through Flexibility and Security", European Commission Directorate - General for Employment, Social Affairs and Equal Opportunities, Unit D.2, Brussels, http:/ /ec.europa.eu/employment_social/employment_strategy/flexicurity\%20media/flexicuritypublication_2 007_en.pdf

European Foundation for the Improvement of Living and Working Condition (2006), "Annual Review of Working Conditions in the EU 2006 - 2007", Office for Official Publications of the European Communities. Luxembourg. http:/ / www.eurofound.europa.eu/do cs/ ewco/tn0702028s/tn0702028s.pdf
European Foundation for the Improvement of Living and Working Condition (2007), "Varieties of Flexicurity: Reflections on Key Elements of Flexibility and Security", Background paper for Hearing on the Commission's Green Paper, 21 March 2007. http://www.eurofound.europa.eu/pubdocs/2007/21/en/ 1/ef0721en.pdf

European Social Partners (2007), “Key Challenges Facing European Labour Markets: A Joint Analysis of European Social Partners", Brussels. http:/ / ec.europa.eu/employment_social/social_dia logue/docs/cross_key_challenges.pdf

European Union Employment Comitee Working Group - EMCO (2006), "Flexicurity", Brussels, http:/ / ec.europa.eu/ employment_social/employment_strategy/pdf/emco_workgroupflexicurity06_en.pdf

Evans, S., Rossiter, A., Mueller, K. ve Menne, V. (2008), "Anglo-Flexicurity: A safety net for UK workers", The Social Market Foundation, London.

Gündoğan, N. (2007), “İşgücü Piyasasında Esneklik - Güvence İlişkisi: Danimarka Modeli", Çimento Endüstri İşverenleri Sendikası Dergisi, 21 (3), 22 - 37.

Hofer, H. (2006), “Reform of Severance Pay Law in Austria", Discussion Paper, Peer Review: Reform of Severance Pay Law in Austria, Vienna. http:/ / pdf.mutuallearning-e m ploym ent.net / pdf/AT06/disspaperPCIE $\% 20 \mathrm{AT} \% 200$ 6.pdf

Keune, M. (2008), “Flexicurity: A Contested Concept at the Core of the European Labour Market Debate", Intereconomics Review of European Economic Policy, $43(2), 92-98$. 
Klammer, U. ve Tillman K. (2001), Flexicurity - Soziale Sicherung und Flexibilisierung der Arbeits- und Lebensverhältnisse, Düsseldorf: WSIHans Böckler Stiftung.

Klec, G. (2007), "Flexicurity and the Reform of the Austrian Severance Pay System", European Economic and Employment Policy Brief, No. 4., ETUI-REHS, Brussels.http://www.fmb.unimore.it/online/Home/documento5293.html

Kluve, J. (2006), “The Effectiveness of European Active Labour Market Policy", IZA Discussion Paper no. 2018, http:/ / ssrn.com/abstract $=892341$

Koman, R., Schuh, U. ve Weber, A. (2005), "The Austrian Severance Pay Reform: Toward a Funded Pension Pillar", Emprica, $32(3-4), 255-74$.

Larsen, M. (2002) "Educational policies", Consensus, cooperation and conflict The policy-making process in Denmark, der. H. Jørgensen, Cheltenham, Edward Elgar, 190-209.

Lehner, U. ve Timar, P. (2006), "Contribution to the EEO Autumn Review 2006 "Flexicurity" - Austria, European Employment Observatory", http://www.euemployment-observatory.net/resources/reports/Austria-FlexicurityAR06. pdf

Leschke, J., Schmid, G. ve Griga, D. (2006), "On the Marriage of Flexibility and Security: Lessons from the Hartz-reform in Germany", Discussion Paper, SP 2006-108, Wissensschaftzentrum Berlin.

Limoncuoglu, S.A. (2006), "Mukayeseli Hukuk ve Türk Hukukunda İşsizlik Sigortasi", Doktora Tezi, Dokuz Eylül Üniversitesi Sosyal Bilimler Enstitüsü, İzmir.
Limoncuoglu S.A. (2008) “The Effects of Cultural Understanding of Family Responsibilities and Family Friendly Governmental (Legal) Programs on Women Participation to Labor Force", Gender, Family Responsibility and Legal Change Konferansi, Sussex Law School, University of Sussex, 10-12 Temmuz 2008.

Madsen, P. K. (1999), “Denmark: Flexibility, security and labour market success", Employment and Training Papers No 53, Geneva: ILO.

Madsen, P. K. (2003), “'Flexicurity' through labour market policies and institutions in Denmark", Employment stability in an age of flexibility. Evidence from industrialized countries, der. P. Auer ve S. Cazes, Geneva, ILO, 59-105.

Madsen, P. K. (2004), “The Danish model of "flexicurity": experiences and lessons", Transfer, 10 (2), 187-207.

Madsen, P. K. (2005), “The Danish road to flexicurity: Where are we. And how did we get there?", Employment policy from different angles, der. T. Bredgaard ve F. Larsen, Copenhagen: DJØF Publishing.

Madsen, P. K. (2006a), "How can it possibly fly? The paradox of a dynamic labour market in a Scandinavian welfare state", National Identity and a Variety of Capitalism: The Case of Denmark, der. J. L. Campbell, J. A. Hall and O. K. Pedersen, Montreal: McGill University Press, 321-355.

Madsen, P.K. (2006b), “Flexicurity - A New Perspective on Labour Markets and Welfare States in Europe", Background paper for presentation at the DG EMPL Seminar on flexicurity, Brussels, May 18, 2006, http:/ / www.epa.aau.dk/fileadmin/user_upload/conniek/Dansk/ Research_papers/3Flexicurity_A_new. pdf 
Ministry of Employment (2005): Større jobskabelser og jobnedlæggelser i Danmark, 1980-2002, Analysepapir 1, serviceeftersyn, Flere i arbejde, Copenhagen: Beskæftigelsesministeriet.

Nickell, S. ve Layard, R. (1999), "Labor market institutions and economic performance," Handbook of Labor Economics, der. O. Ashenfelter ve D. Card, edition 1 , volume 3 , chapter 46 , 3029-3084 Elsevier, North-Holland Press.

OECD (2004), Employment Outlook, OECD Press, Paris.

OECD (2006), Employment Outlook, OECD Press, Paris.

OECD (2007), Employment Outlook, OECD Press, Paris.

Philips, K., Eamets, R., Alloja, J., Krillo, K. ve Lauringson, A. (2007), "Approaches to Flexicurity: EU Model"s, European Foundation for the Improvement of Living and Working Conditions, Luxembourg, Office for Official Publications of the European Communities. http:/ / www.eurofound.europa.eu/pu bdocs/ 2007/84/en/1/ef0784en.pdf

Pitruzzello, S. (1999), Decommodification and the Worlds of Welfare Capitalism: a Cluster Analysis, Florence, European University Institute.

Pylkkanen, E. and Smith, N. (2004), "The Impact of Family-Friendly Policies in Denmark and Sweden on Mothers' Careeer Interruptions Due to Childbirth", IZA Discussion Paper No. 1050. $\mathrm{ftp}$ :/ / repec.iza.org/RePEc/Discussionpaper/dp1050.pdf

Sapir, A. (2006) "Globalization and the Reform of European Social Models", Journal of Common Market Studies, 44 (2), $369-90$.
Schippers, J., Henderikse, W. ve Swierts, K. (2007), "Contribution to the EEO Autumn Review 2006 "Flexicurity" - The Netherlands", European Employment Observatory, http://www.eu-employment-observatory.net/resources / reports/Netherlands-Flexicurity AR06. pdf

Schmid, G. and K. Schönmann (1999), “Von Dänemark lernen - Learning from Denmark", WZB Discussion Paper FS I 99201, Wissenschaftszentrum Berlin für Sozialforschung, Berlin.

Tangian, A. (2005), "Monitoring flexicurity policies in the EU with dedicated composite indicators", Paper presented at the conference of the International Employment Association (IERA), Alborg, 26- 29 June 2005. http:/ / ec.europa.eu/ employment_social/employment_anal ysis/docs/050318_tangian_pres_en.pdf

Tangian, A. (2006), "European flexicurity: concepts (operational definitions), methodology (monitoring instruments), and policies (consistent implementations)", WSI Diskussionspapier 148, Hans Böckler Stiftung, Düsseldorf.http://www.boeckler.de/p df/p_wsi_diskp_148_e.pdf

Vermeylen, G. ve Hurley, J. (2007), “Varieties of flexurity : Reflections on key elements of lexibility and security", Background paper, European Foundation for the Improvement of Living and Working Conditions, Dublin.

Watson, C.M., Bakker, B.B., Martijn, J.K. ve Halikias, I. (1999), "The Netherlands Transforming a Market Economy", International Monetary Fund, Washington D.C. 
Wilthagen, T. (2002), “The Flexibility - Security Nexus : New Approaches to regulating employment and labour markets", British Journal of Industrial Relations, "The Politics of Employment Relations" Konferansı için makale, Windsor. http://www.uvt.nl/osa/producten/wop/oswp02_18.pdf

Wilthagen, T., Tros, F. ve Van Lieshot, $\mathrm{H}$. (2003), “Towards 'flexicurity': balancing flexicurity and security in EU member states" Invited paper for the 13th Worl Congress of the IIRA, Berlin.

http:/ / www.tilburguniversity.nl/faculties/law/research/flexicurity/publications/papers/fxp2003_3.pdf

Wilthagen, T. ve Tros, F. (2004), “The Concept of Flexicurity: A New Approach to Regulating Employment and Labour Markets", European Review of Labour and Research, 10(2), $166-187$.

Wilthagen, T., Bekker S. ve Schippers, J. (2006), "Taking action on transtional labour markets", Paper presented at the ILP conference, Amsterdam,

Wilthagen, T. (2007), Flexicurity Practices, European Expert Group on Flexicurity, Brussels. http:/ / ec.europa.eu/employment_social/employment_strategy/pd f/flexi_practices_en.pdf

World Bank (2004), Doing Business in 2004 Understanding Regulations, Oxford University Pres, Washington, D.C. 